\title{
PERFORMANCE DETERMINANTS OF THE INSURANCE COMPANY'S ACTIVITY
}

\author{
Ionut LOM ${ }^{1}$, PhD Student, \\ State University of Moldova \\ Lilian MARIN², PhD Student, \\ Academy of Economic Studies of Moldova
}

DOI: https://doi.org/10.36004/nier.es.2020.1-02

JEL Classification: G20, G22

UDC: 368

\section{ABSTRACT}

Considering the growing role of the insurance protection function in a dynamic business environment, the issue of efficient management and solvency of insurance companies is becoming a priority. The purpose of this study is to identify the performance determinants of the insurance business. To achieve this goal, the authors researched methodological aspects of assessing the financial performance of the insurance company in terms of absolute and relative indicators of financial results. The authors consider that profit and profitability indicators are important to give a quantitative and qualitative assessment to the financial management of companies. The monographic method and the causal explanation were applied to concretize the model for forming the overall financial result of the insurance company. The methodological approach in order to test the hypothesis was made by adapting the factorial model for analysing the profitability of sales revenues to the specifics of the insurance company's activity. Profit and profitability indicators play an important role in the process of qualitative and quantitative evaluation of the company's financial management. The analyses performed by the authors based on the public financial statements of the insurance company "Acord Grup" SA, the reports of the National Financial Market Commission (NCFM) and the reports of the Romanian Financial Supervisory Authority (FSA) highlighted the decreasing trend of profitability indicators of insurance companies. In order to react as quickly as possible and manage the given situation, the authors recommend to the managers of the insurance companies to apply the factorial analysis models, in order to capture the determinants of the profitability indicators of the insurance activity, which require an increased attention.

Keywords: insurance, profit, profitability, performance, factorial model, insurance portfolio.

Având în vedere rolul crescând al funcției de protecție a asigurărilor într-un mediu de afaceri dinamic, problema gestionării eficiente și solvabilității societăților de asigurare devine o prioritate. Scopul acestui studiu constă în identificarea factorilor determinanți ai performanței activității de asigurări. Pentru realizarea acestui scop autorii au cercetat aspectele metodologice ale evaluării performanței financiare a societății de asigurări prin prisma indicatorilor absoluți și relativi ai rezultatelor financiare. Autorii consideră că indicatorii de profit și rentabilitate sunt importanți pentru a da o apreciere cantitativă și calitativă gestiunii financiare a societăților. Metoda monografică și explicația cauzală au fost aplicate pentru concretizarea modelului de formare a rezultatului financiar global al societății de asigurări. Demersul metodologic în vederea testării ipotezei s-a realizat prin adaptarea modelului factorial de analiză a rentabilității veniturilor din vânzări la specificul activității societății de asigurări. Indicatorilor de profit și rentabilitate le revine un rol important în procesul de evaluare calitativă și cantitativă a gestiunii financiare a companiei. Analizele efectuate de autori în baza Situațiilor financiare publice ale societății de asigurări „Acord Grup” S.A., a rapoartelor Comisiei Naționale a Pieței Financiare (CNPF) și a rapoartelor Autorității de Supraveghere Financiară din România (ASF) au scos în evidență tendința de descreștere a indicatorilor de profitabilitate a societăților de asigurări. Pentru a reacționa cât mai promt și gestiona situația dată, autorii recomandă managerilor societăților de asigurări să aplice modele de analiză factorială, pentru a surprinde factorii determinanți ai indicatorilor de rentabilitate ai activității de asigurare, care necesită o atenție sporită.

Cuvinte-cheie: asigurări, profit, rentabilitate, performanță, model factorial, portofoliu de asigurări.

1 @ IonuțLOM, $₫$ lom.ionut@incas.ro

2 @Lilian MARIN, $₫$ marinlilian8@gmail.com 
Учитывая растущую роль функции страховой защиты в динамичной бизнес-среде, проблема эффективного управления $u$ платежеспособности страховых компаний становится приоритетной. Целью данного исследования является выявление факторов, определяющих эффективность страхового бизнеса. Для достижения этой цели авторы исследовали методологические аспекты оценки финансовых показателей страховой компании по абсолютным и относительным показателям финансовых результатов. Показатели прибыли и рентабельности важны для количественной и качественной оценки финансового менеджмента компаний. Монографический метод и причинно-следственная связь были применены для конкретизации модели формирования общего финансового результата страховой компании. Для проверки гипотезы факторная модель анализа доходности выручки от продаж была адаптирована к специфике деятельности страховой компании. Аналитические данные по компаниям и по отрасли были обработаны с использованием сравнительного анализа, табличного и графического метода. Показатели прибыли и рентабельности важны для количественной и качественной оценки финансового менеджмента компаний. Анализ, выполненный авторами на основе публичной финансовой отчетности страховой компании "Acord Grup" SA, а также отчетов Национальной комиссии по финансовому рынку и Органом по финансовому надзору Румынии (FSA) выявил тенденцию к снижению показателей эффективности страховых компаний. Чтобы вовремя реагировать и управлять ситуацией, авторы рекомендуют менеджерам страховых компаний применять модель факторного анализа, чтобы охватить факторы, определяющие показатели эфФективности страховой деятельности компании, которые требуют особого внимания.

Ключевые слова: страхование, прибыль, рентабельность, эффективность, факторная модель, страховой портфель.

\section{INTRODUCTION}

Insurance is considered one of the most important components of the financial market, thus contributing towards the increasing of the efficiency of all areas of activity. The current conditions of economic development and society determine special conditions with regard to the financial stability of insurance companies as a strategic factor in the economic security of social reproduction, increasing business activity and improving the investment climate.

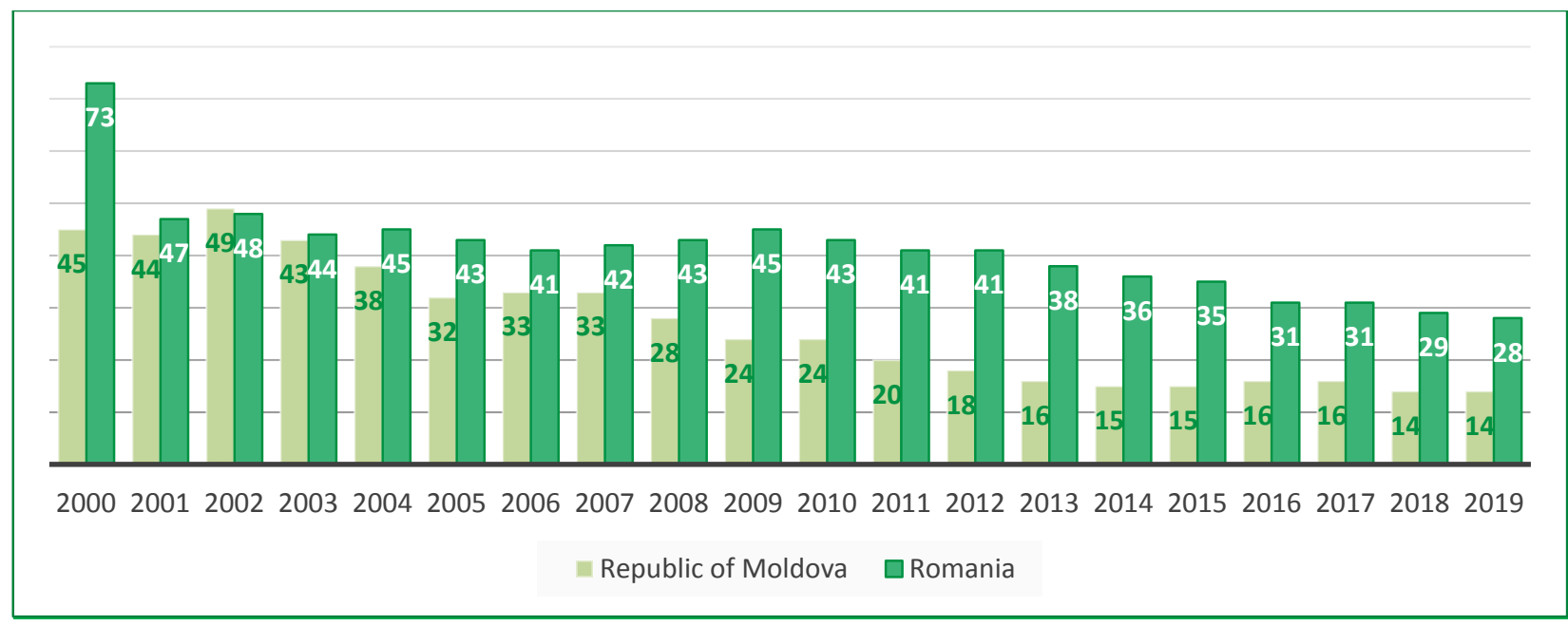

Figure 1. Dynamics of the number of insurance companies in RM and Romania, 2000-2019

Source: Elaborated by authors based on the reports of the National Commission for Financial Markets of the Republic of Moldova and of the Romanian Financial Supervisory Authority [1]

https://asfromania.ro/publicatii/rapoarte-anuale/rapoarte-asf

https://www.cnpf.md/ro/rapoarte-anuale-6315.html 
Recently, we are witnessing an involution of the insurance market in the Republic of Moldova, given that the management of companies has made changes in their development strategy. For example, Aliance Insurance Grup JSC and Asito JSC together with other companies went through reorganizations, which resulted in the restructuring of business processes, changes in shareholding and the name of the company, but failed to overcome the financial difficulties. Therefore, in 2018, the NCFM withdrew the activity licenses of these two companies.

We are witnessing a shrinking of the insurance market in the last two decades. Both in the Republic of Moldova and in Romania the number of insurance companies decreased significantly (figure 1).

Such a conclusion also results from the dynamics of the main performance indicators specific to the insurance field: the insurance degree of penetration and density. If the insurance density registered a modest increase, then the downward dynamics of the degree of penetration in the last 6 years clearly reflects the involution of this field with negative macroeconomic implications (figure 2).

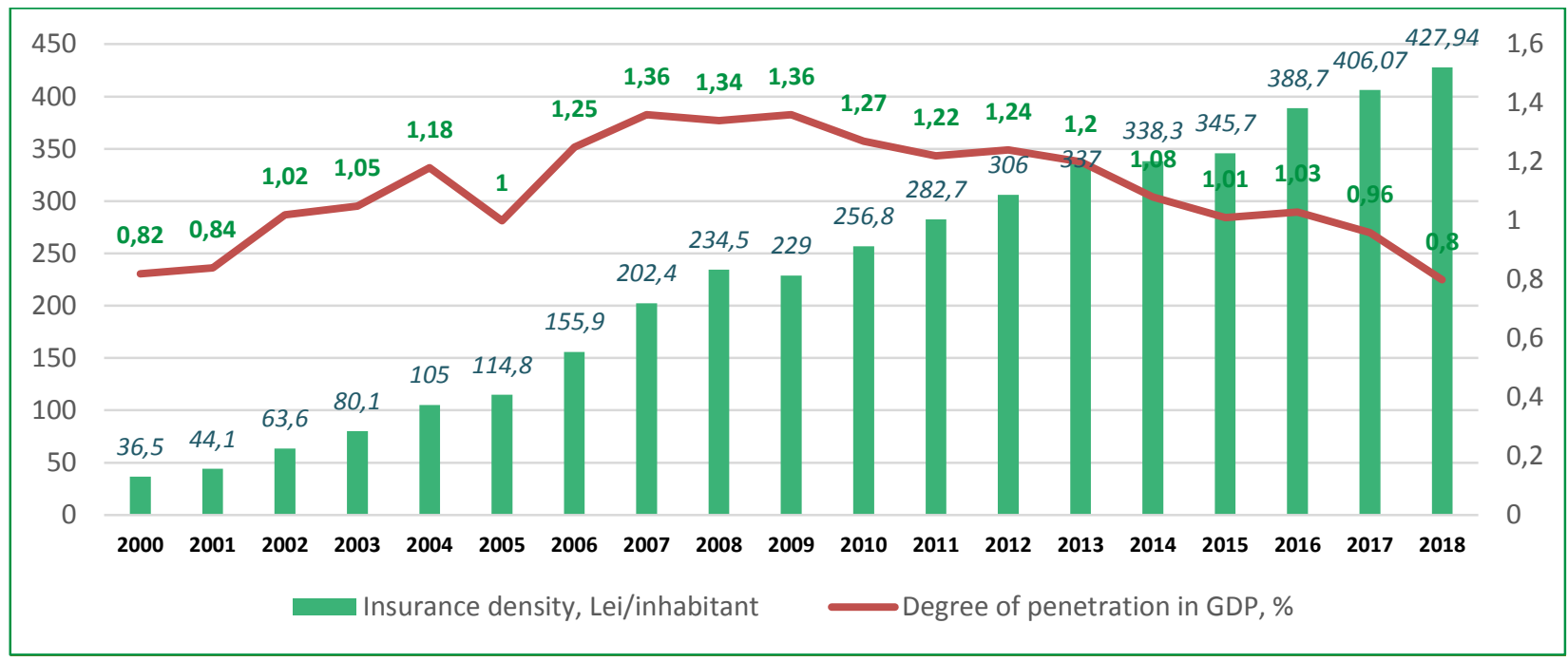

Figure 2. The evolution of the main performance indicators of the insurance field in the Republic of Moldova (2000-2018)

Source: Elaborated by authors based on NCFM reports [2].

At the base of the performance indicators of the insurance field are the insurance premiums, which, viewed individually at the level of the insurance company, represent a determining factor of its performance. Insurance premiums determine the level of solvency, as by collecting premiums the company supplies itself with liquidity. At the same time, insurance premiums represent a factor that influences the size and quality of performance indicators (profit or loss).

In the context of the above mentioned, the research hypothesis was formulated: the financial performance of the insurance company depends on the size of the premiums collected from the insurance contracts and the compensation expenses.

This problem' solving requires an appropriate methodological approach for the financial performance indicators, which ensures an in-depth analysis of the profit-generating activities specific to the insurance field.

\section{LITERATURE REVIEW}

In the authors' opinion, at the present stage, both the analysts and managers of the insurance companies in the Republic of Moldova, as well as in Romania pay a great attention to solvency and liquidity indicators, considering the fact that management must be oriented towards sustainable growth, which requires a periodical monitoring of the economic and financial situation. Such an audit is performed with the methodological tools of the financial analysis specific to the insurance field. In the specialized literature different methodological approaches to the financial analysis of the insurance companies' activity are described [3, Văcărel, I., BERCEA, F, 2006]. Most often they address 
the issue of financial solvency, the sufficiency of assets that form the reserves of the insurance company. A complex analysis of the financial situation of the insurance company is recommended by the National Association of Insurance Companies (NAIC). [GHINZURG A. 2006].

At the same time, to be considered rational, economic activities must generate profit. Profit is perceived as a force that directs the market economy and is the raison d'être of any economic entity, being considered a gain that remunerates the basic, classic factors of production: capital, land and labour.

According to the modern theory of financial management, the fundamental goal of any company is to maximize the market value. The value of the company is perceived as an indicator of future opportunities to increase its revenues. Given this aspect, in the strategic vision, the profitability indicator can be considered an indicator that characterizes the degree of growth of the market value of the insurance organization.

The methodological tools for assessing the market value of companies are largely based on indicators of economic profit, free cash flow and their changes. Economic profit is interpreted as the added value obtained by the company's owners over the value, they could achieve from optional investment alternatives. Thus, a positive economic profit reflects the value creation and the efficient use of capital. The positive net cash flow reflects the result of cash flows over a given period of time, reflecting the excess when cash inflows exceed payments. The expected cash flows, discounted at a discount rate that takes into account the risks of the organization, determine the market value of the insurance company.

Each of the methods of estimating the market value has its advantages and disadvantages, following which it is usually recommended to use a combination of them (for example, EVA, SVA and CFROI) followed by a comparative analysis of the financial results [Tabără, Vasiliu 2006; Copeland et al. 2000]. When selecting an appropriate model for analysing the financial performance of the insurance company, their growth strategy, current status and estimates of the evolution of the business environment must be taken into account.

Many opinions emphasize the importance of the goal of profit maximization, but mention that it should not be an end in itself, because the insurance company participates in the redistribution of national income, not in its creation. The largest contribution to the financial result must come from the investment activity. In addition, the established insurance reserves, being temporarily free resources, are also becoming an important source of investment. The profit from the investment and financial operations must have the largest share in the total amount of the profit. The investment profit allows the insurance company to pay on time the indemnities, the extension of the activity, the reduction of the insurance tariffs, etc. [Văduva 2010]. Thus, the profit obtained from the investments made on account of the reserves can be used to extend the insurance liability; reducing tariffs on insurance products, and this contributes to increasing the competitiveness of the insurance company.

Profit as an indicator that fully expresses the efficiency of the insurance company's activities is important, but only in base of profit indicators it is impossible to give an objective assessment of success or decline in performance during that period, because the same amount of profit can be the result of different activities of the insurer.

Some general conclusions on profitability derived from the analysis of the financial results' indicators expressed in absolute terms lead to the idea that the efficiency of insurance companies in the Republic of Moldova has a downward trend, confirmed by data on financial results in insurance presented by the NCFM [NCFM] in the quarterly and annual reports. Thus, according to the cumulative profit before tax indicator in the field at the situation from the end of 2019, the sector recorded losses in the amount of 10,33 million lei. Out of 14 insurance companies in the Republic of Moldova, 6 insurers ended the financial year with losses. In the context of the above mentioned, we consider of great actuality the approach to the issue of profitability management within insurance companies.

\section{RESEARCH METHODOLOGY}

Insurers, as subjects of entrepreneurship, manage a potential of resources, whose capitalization has as main objective profit generation. We can speak of profit when the total income of the activity of a company exceeds the total expenses, the profit representing the surplus of income over the expenses made by the enterprise. Profit is often used as a measure of performance or as a basis for 
other indicators, such as profitability (activity, investment) or earnings per share. Profitability reflects the company's ability to produce profit (positive result), reflecting in a synthetic form the efficiency of its entire economic activity and is one of the expression forms of economic efficiency.

The financial result of the operational activity of the insurer obtained during the reporting period, expressed in profit or loss, characterizes the success or failure/unsuccess of the activity in terms of quality and quantity.

The general model of the formation of the insurance company's financial result can be represented in the following way:
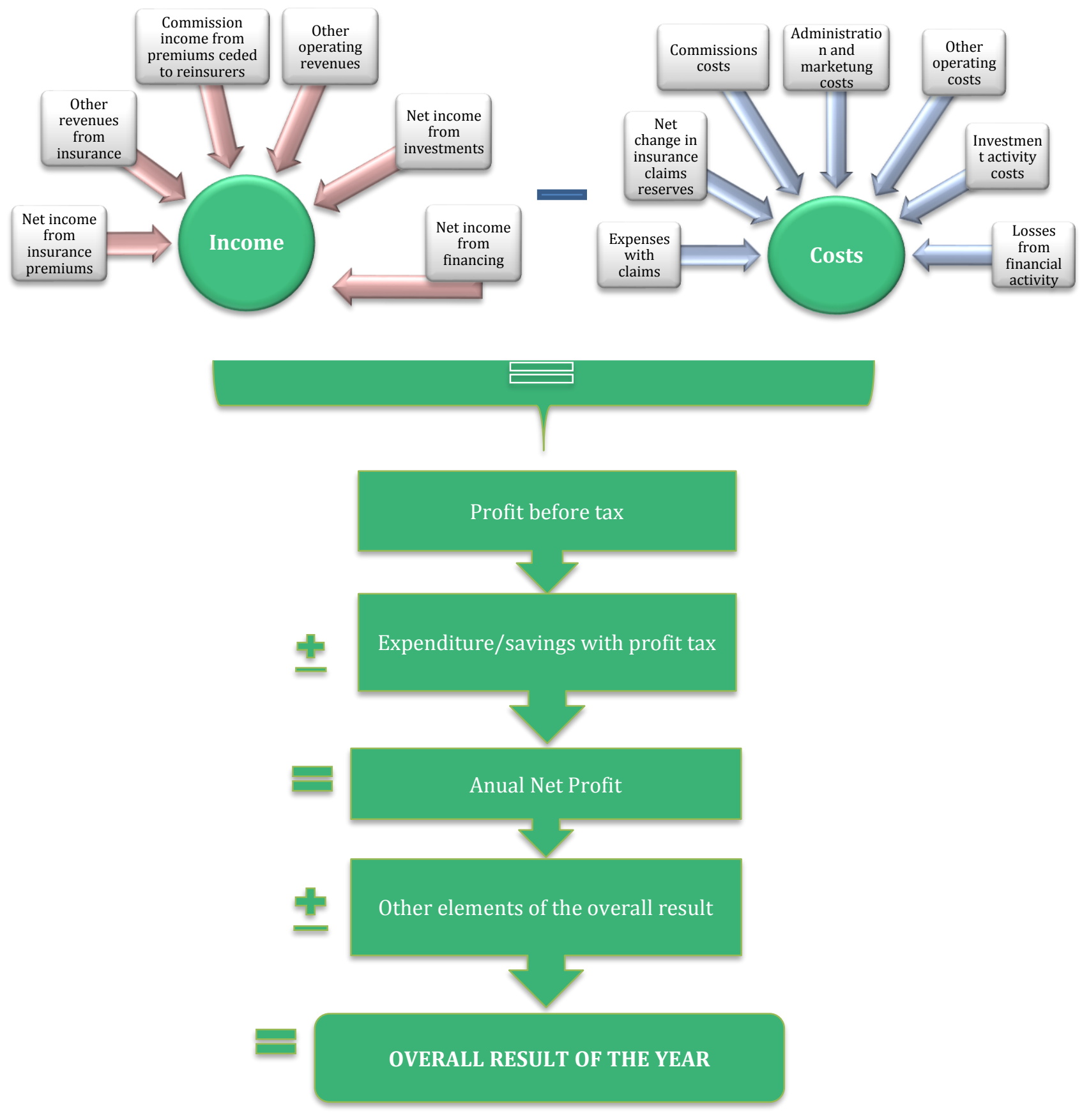

Figure 3. The general model of formation of the insurance company's financial result Source: Elaborated by authors based on the Financial Statements of the Board of Directors "Donaris Vienna Insurance Group JSC and "Klassika Asigurări" JSC; "Acord Grup" JSC, „Euroins Romania Asigurare-Reasigurare" JSC [8; 9; 10; 11]. 
The above mentioned in figure 3 allow us to find that the interim financial results and the overall result (the absolute indicators of financial performance) are formed progressively, based on a "cascading succession" mechanism due to the continuous chain of operations (receipts of premiums, payments of compensations, interest receivables from securities' investment fees, payments of commissions to brokers, etc.), that characterize the activity of the insurance company. The analysis of the financial results of the insurance company is performed based on the elements included in the Profit or Loss Statement or the Statement of the global result that summarizes the economic flows, respectively the expenses and revenues of the management period, resulting from insurance, investment, financing and other activities.

If we refer to the efficiency of the financial management of the joint stock company, we consider that the managerial performance indicator of the insurance company is nevertheless the net profit, which can be presented in the following way:

Net result $=$ Total revenues - Total expenditure

Revenues $=$ Net income from insurance $/$ reinsurance activities + net income $/$ investment gains + net income / gains from financing

Expenditure $=$ Operating $/$ operational expenses + net financing costs

The formalized model (1) highlights that the positive financial result of the insurer's activities largely depends on 2 basic components:

1) Net income from underwriting insurance contracts;

2) Net investment income.

These, in turn, determine the size of other performance indicator of the insurance company - the profit before tax.

The application in analytical practice of profitability indicators eliminates this disadvantage, a fact confirmed by the studies conducted by Moskaleva E. [Moskaleva 2013]. Profitability indicators reflect the efficiency of the establishment, distribution and capitalization of the financial resources of the insurance company, i.e. the optimum of its financial result. Profitability is a synthetic form of expressing economic efficiency, which reflects the ability of a company to obtain a profit or a benefit from the activity it carries out. Profitability is measured by the ratio between the results (a profit indicator (gross, net, etc.) and the means (resources or capital) used to obtain them [NBS]. In the process of analysing the efficiency indicators, it is necessary to determine correctly from a methodological point of view the total amount of income and expenses realized from the insurance, investment and other activities.

Thus, Moskaleva E. highlights the role of profitability indicators viewed through the prism of their analysis by stakeholders [Moskaleva 2013]:

- A high level of profitability contributes to increasing the financial stability of the insurance company (the risks associated with the possible non-fulfilment of obligations to pay damages are reduced); the company is able to face a fierce competition in the insurance market;

- Profitability is of particular importance for owners (shareholders), because, when it increases, the interest for investments in this insurance company increases, the share price increases, respectively the objective of maximizing the market value of the capital invested by them is achieved;

- For entrepreneurs, a profitability indicator characterizes the attractiveness of a business in this field, showing how insurance justifies investment expectations compared to alternative areas of capital investment.

In order to correspond to the rigors imposed by the financial environment, the modern financial management comes to the aid with specific management methods, tools and levers, oriented towards the achievement of the object of activity in normal conditions of profitability. Normal conditions of profitability are considered when the entity obtains a sufficient gain to continue operating under normal conditions and corresponding to the degree of risk to which it is exposed. The main indicators of profitability, calculated on the basis of the data of the public financial statements of insurers, can be systematized in the following three categories:

1) indicators that characterize the efficiency of insurance activities and insurance operations;

2) indicators that characterize the efficiency of the insurer's investment activities;

3 ) indicators that characterize the return on invested capital (figure 4). 


Indicators of the insurance
activity profitability
-Profitability of insurance
operations
-Profitability of the insurance/
operating activity

Indicators of the investment activity profitability

- Return of investment

- Return of investment of insurance reserves
Indicators of the return of the advanced capital

- Return of assets

- Return of equity

-Profitability of permanent capital

-Profitability of net assets

Figure 4. Categories of profitability indicators of insurance companies

Source: Elaborated by authors.

One solution to capture several aspects of profitability is to apply a complex indicator of profitability. An example suggested by Moskaleva E. is based on an additive model (4), which reflects the results of different activities on the basis of reporting - gross insurance premiums, which allows us to estimate their contribution to the overall profitability of the insurance company of all subsystems, its functions: insurance, investment and reinsurance [Moskaleva 2013]:

$$
K_{R}=\frac{R_{\text {op.as }}}{P B S}+\frac{\text { Rnet }_{I N V}}{P B S}+\frac{R_{C R}}{P B S}
$$

Where:

$K_{R}$ - the complex / integral coefficient of the profitability of the insurance company;

$R_{\text {op.as. }}$ - the net result of insurance operations;

Rnet $_{I N V}$ - the net result of investment activity;

$R_{C R}$ - benefits or damages related to reinsurance contracts;

$P B S$ - gross insurance premiums written during the period.

One of the performance indicators of the insurance company is the Return on Assets (ROA), calculated according to relation (5) and shows the contribution of a Leu invested in assets to the formation of profit. Along with the indicator "Return on Capital (ROE)", it is considered one of the most important indicators of the activity of an insurance company, because it "...highlights the way in which managers of society use the total resources of society (financial and real) to get profit".

$$
R O A=\frac{\text { Pnet }}{\bar{A}} \times 100,
$$

Where:

ROA - assets rentability (Return on Assets);

Pnet - net profit;

$\bar{A}$ - the average annual value of the assets.

The assessments of the rate of return on assets allow comparisons with other insurance companies. According to this profitability indicator, stakeholders are informed about the capacity of economic capital to ensure its renewal and remuneration as a factor.

Relevant assessments regarding the level of profitability rate are given by correlating their value with the existing averages in the branch or sector of activity. The average profitability of assets in the field of activity "Financial and insurance activities" in 2016 was 3,9\%, and in $2017-6,2 \%$. In 2016, only 5 companies out of the 9 analyzed exceeded the average level of ROA in the given field of activity. In 2017, only 3 insurance companies exceeded the level of $6,2 \%$ of the return on assets.

The rate of return on assets, in some situations is assessed in correlation with the evolution of the inflation rate. A rate of return on assets above the inflation rate will be able to ensure the preservation of the "economic substance" of the enterprise and even the renewal and growth of its economic assets, in the shortest possible period.

An important qualitative indicator of the insurer's activity is considered the Profitability of the insurance activity (6) which is of interest not only to the owners and administrators of the insurance company, but primarily to external users: consultants, financial analysts, potential investors and shareholders. External users have the opportunity to assess the profitability of the insurance company 
only on the basis of the public financial statements of the insurer, which they are required by law to publish, in their capacity as public interest entities, one of the indicators being profit before tax. However, considering that the profit before tax is an indicator expressed in absolute terms, the result obtained "...does not always give the possibility to objectively assess the effectiveness of the operational activity without resorting to profitability indicators." [Balanuța 2010]. The interpretation of this hypothesis with reference to the insurance activity, allows us to conclude that the profitability of the insurance activity $\left(R_{A}\right)$ is an indicator that reflects the performance of the management team, calculated as the ratio between profit before tax and total income.

$$
R_{A}=\frac{P I}{V S} \times 100,
$$

Where: $R_{A}$ - profitability of the insurance activity, \%;

$P I$ - profit before tax;

$V S$ - income from underwriting insurance contracts;

$$
P I=V S-C h E \text { (Operating expenses) }
$$

The change in dynamics of the profitability indicator of the insurance activity is important for different categories of users, because it highlights a series of factors, which influence the resultant indicator. Moreover, taking into account the free access to the financial statements of companies, we can compare with other insurance companies operating in the market and their dynamic evolution.

RESULTS AND DISCUSSIONS

The factor analysis can determine the influence of a number of factors. In the present study we will refer to the analysis of the profitability of the insurance company's activity through the prism of the analysis of three factors:

- Changing the structure of the insurance portfolio;

- Modification of expenses related to the insurance activity;

- Changing the amount of insurance rates.

We will apply the factorial model (7) to analyse the profitability of the insurance activity based on the Profit or Loss Account of the insurance company "Acord Grup" JSC for the period 2017-2018. The initial data are presented in table 1.

\section{Initial data for the factorial analysis of the insurance activity profitability}

Table 1 in dynamics of the insurance company „Acord Grup” JSC

\begin{tabular}{|l|c|c|c|c|}
\hline \multicolumn{1}{|c|}{ Indicator } & $\begin{array}{c}\text { Conventional } \\
\text { signs }\end{array}$ & 2017 & $\begin{array}{c}\text { The year 2018 } \\
\text { recalculated in the } \\
\text { conditions of 2017 }\end{array}$ & 2018 \\
\hline \begin{tabular}{l|c|c|c|} 
Income from underwriting \\
insurance contracts, thousand lei
\end{tabular} & $V S$ & 58245,19 & 53754,0 & 55769,34 \\
\hline Operating expenses, thousand lei & $C h E$ & 45852,92 & 51543,37 & 47571,18 \\
\hline Profit before tax, thousand lei & $P I$ & 8930,94 & 2210,63 & 10239,31 \\
\hline $\begin{array}{l}\text { Profitability of the insurance } \\
\text { activity, \% }\end{array}$ & $R_{A S}$ & 15,33 & 4,11 & 18,36 \\
\hline Sourc: & & & & \\
\hline
\end{tabular}

Source: Authors' calculations based on the Financial Statements of the Insurance Company "Acord Grup "for the years 2017-2018.

The recalculation of the indicators of 2018 in the conditions of 2017 was made based on the calculation methodology of the scientist Vl. Balanuță [Balanuța 2010]. The following calculations were performed to determine the influencing factors:

Recalculated profitability of the insurance activity I $\left(R_{A S r e c l}\right)$ :

$$
R_{\text {ASrecl }}=\frac{V S_{r e c}-C h E_{r e c}}{V S_{r e c}} \times 100=\frac{53754,0-51543,27}{53754,0}=4,11 \%
$$


Recalculated profitability of the insurance activity II $\left(R_{A S r e c I I}\right)$ :

$$
R_{\text {ASreclI }}=\frac{V S_{\text {rec }}-C h E_{2018}}{V S_{\text {rec }}} \times 100=\frac{53754,0-47571,18}{53754,0}=11,50 \%
$$

In 2018, the profitability of the insurance activity of the insurance company "Acord Grup" JSC increased by 3.03 p.p. The influence of the factors stated above is as follows:

Changing the structure of the insurance portfolio:

$\Delta R_{A S}\left(f_{1}\right)=4,11-15,33=-11,22$ p.p.

Modification of the expenses related to the insurance activity:

$\Delta R_{A S}\left(f_{2}\right)=11,50-4,11=+7,39$ p.p.

Changing the amount of insurance rates:

$\Delta R_{A S}\left(f_{3}\right)=18,36-11,50=+6,86 p \cdot p$.

Verification: $-11,2+7,39+6,86=+3,03$

From the three factors stated above, we conclude that the change in the structure of the insurance portfolio mitigated the increase in the profitability of the insurance business of the insurance company "Acord Grup" JSC in 2018 compared to the previous year. Its negative impact determined a decrease of the resultant factor by 11.22 p.p., and the other two factors had a positive influence.

In order to establish the influence of other indicators on the performance indicators of this company, the authors deepened the analytical approach by determining the influence of changing the structure of the insurance portfolio on another important indicator, which determines the company's solvency - net premiums and represents the company's turnover.

Creating a sustainable portfolio is an important goal of the organization. The insurance portfolio characterizes the financial reliability of the company. This is a set of contracts concluded for certain amounts of insurance. In fact, it is a reflection of the company's obligations to customers. The degree of responsibility of the structure within the adopted contracts depends on its size. In order to ensure the sustainability of activities, it is reasonable to create an insurance portfolio with a large number of lowliability transactions. The payment of compensation should not affect the company's financial situation. The insurance portfolio is the main source of cash, and if the structure is poorly managed, it can cause the organization to go bankrupt. Therefore, it is important to form and correctly distribute the risks and liability in contracts. However, reinsurance services are not free. It is therefore necessary to assess the economic efficiency of the transaction before it is concluded.

As it results from the Profit or Loss Account and the statement of other elements of the overall result of the Insurance Company "Acord Grup" JSC, for the financial year ended December 31, 2018 the written gross insurance premiums increased compared to the previous year by 7521,77 thousand lei. This deviation was formed under the influence of the change of the following two factors:

1) number of insurance contracts;

2) the average premium received per contract.

The influence of each factor was analysed based on table 2 .

Table 2

Initial data and calculations related to the evaluation of the factors' influence on the net premium subscribed by the Insurance Company "Acord Grup" (2017-2018)

\begin{tabular}{|l|c|c|c|}
\multicolumn{2}{|c|}{ Indicator } & \multicolumn{2}{c|}{$\begin{array}{c}\text { Actual data } \\
\text { Absolute } \\
\text { deviation (+,-) }\end{array}$} \\
\hline Number of insurance contracts concluded & 2017 & 2018 & \\
\hline The average premium received per one contract, lei & 71246 & 81095 & +9849 \\
\hline Written net premiums, thousand lei & 797,1 & 798,21 & $+1,1$ \\
\hline $\begin{array}{l}\text { including, based on: } \\
\text { Increase in number of concluded contracts: 9849 x 797,1 }\end{array}$ & & & $+7940,75$ \\
\hline $\begin{array}{l}\text { Increase in average net written premium per one } \\
\text { contract: +1,1 x 81095 }\end{array}$ & & & $+7850,65$ \\
\hline
\end{tabular}

Source: Authors' calculations based on the Financial Statements of the Insurance Company "Acord Grup "for the years 2017-2018. 
The calculations show that the amount of net written premiums increased only due to the growth in the number of concluded contracts, the increase being 7850 thousand lei. The amount of the average premium received practically remained at the same level, respectively did not have a significant influence on the change of the net amount of the subscribed premiums.

\section{CONCLUSIONS}

Given the conditions imposed by the competitive environment, but also by the supervisory bodies of the non-banking financial market, the insurance company must have as basic objectives the assurance of the profitability and liquidity necessary for a continuous activity. Respecting these fundamental objectives, the insurance company will make enough profit to remunerate the owners and to compensate the insured if necessary. Failure to meet the objectives of profitability and liquidity may condition a state of financial imbalance, insolvency and non-compensation of policyholders in case of insured risks.

From the systematization of the methodological approaches for analysing the efficiency of the insurance activity, we considered that an efficient financial management requires an integrated approach to the profitability indicators, which can be achieved through factor analysis. This will allow managers to determine the causes, the influencing factors and to make managerial decisions regarding the increase of the efficiency of the activity and the financial performance of the insurance company.

\section{BIBLIOGRAPHY}

1. THE FINANCIAL SUPERVISORY AUTHORITY. Annual reports [citat 14.03.2020]. Disponibil: https://www.cnpf.md/ro/rapoarte-anuale-6315.html

2. NATIONAL COMMISSION FOR FINANCIAL MARKETS. Annual reports [citat 15.03.2020]. Disponibil: https://www.cnpf.md/ro/rapoarte-anuale-6315.html

3. VĂCĂREL, I., BERCEA, F. Asigurări şi reasigurări. București: Editura Expert, 2006.

4. GHINZURG, A.I. Prikladnoj èkonomičeskij analiz. Piter, 2005. 320 s. ISBN 5-469-00248-9.

5. TABĂRĂ, N., VASILIU, A. Relevanța indicatorilor în măsurarea performanțelor întreprinderii. In: Economica. 2013, nr. 1 (83), pp. 81-93. ISSN 1810-9136.

6. COPELAND, T. E., KOLLER, T., \& MURRIN, J.Valuation: Measuring and managing the value of companies. New York: Wiley, 2000.508 p. ISBN 0-471-36190-9.

7. VADUVA, M. Eficiența activități de asigurare în România. In: Annals of the University "Constantin Brâncuşi" from Târgu Jiu. Series Economie. 2010, nr. 2, pp. 149-164. ISSN 1844-7007.

8. DONARIS VIENNA INSURANCE GROUP SA. Raportul financiar al companiei de asigurare. 2018. 13 p. [citat 23.03.2020]. Disponibil: http://www.donaris.md/uploadedfiles/5ccaf86d6e6ce.pdf

9. KLASSIKA ASIGURĂRI JSC. Raportul annual al Companiei pentru anul 2018 [citat 23.03.2020]. Disponibil: https://klassikaasig.md/images/pdf/Raportul\%20anual\%20al\%20Companiei\%20pentru\%20anul\%202 018.pdf

10. ACORD GRUP JSC. Situații financiare individuale. 2018. 54 p. [citat 23 martie 2020]. Disponibil: http://acordgrup.md/app/uploads/2019/04/Situatii-financiare-la-31-Decembrie-2018.pdf

11. EUROINS ROMANIA ASIGURARE-REASIGURARE JSC. Situații financiare IFRS 2018 [citat 24.03.2020]. Disponibil: https://www.euroins.ro/media/Euroins\%20

_\%20Situatii\%20financiare\%20IFRS\%202018\%20_semnat.pdf

12. MOSKALEVA, E.G. Metodika analiza rentabel'nosti deâtel'nosti strahovoi kompanii po dannym publičnoi buhgalterskoj otčetnosti. In: Meždunarodnyj buhgalterskij učet. 2013, № 46, ss. 30-40. ISSN 2073-5081.

13. NATIONAL BUREAU OF STATISTICS. [citat 25.03.2020]. Disponibil: https://statistica.gov.md/pageview.php?l=ro\&id=2254\&idc=351 ovo

14. MOSKALEVA, E.G. Metodičeskie podhody k provedeniû faktornogo analiza finansovogo rezul'tata deâtel'nosti strahovoj kompanii. In: Finansy i kredit. 2013, № 40 (568). ISSN 2071-4688 [citat 28.03.2020]. Disponibil: https://cyberleninka.ru/article/n/metodicheskie-podhody-k-provedeniyu-faktornogo-analizafinansovogo-rezultata-deyatelnosti-strahovoy-kompanii

15. BALANUȚA, Vladimir. Analiza rentabilității veniturilor din vânzări ale întreprinderii prin prisma aportului propriu al colectivului de muncă. In: Analele ASEM. Ediția a VIII-a. Chișinău, 2010, pp. 310-312. ISBN 9789975-75-534-4, ISSN 1857-1433 [citat 30.03.2020]. Disponibil: https://ibn.idsi.md/sites/default/files/imag_file/51.Analiza\%20rentabilitatii\%20veniturilor\%20din\%20v inzari.pdf

\section{ARTICLE HISTORY}

Received 14 May 2020

Accepted 27 May 2020 